\title{
Composition Studies on Tobacco XXXIII Changes in Smoke Composition and Filtration by Artificial Alteration of Smoke pH:
}

\author{
Pyridine and Nicotine*
}

\author{
by R. L. Stedman, L. Lakritz and E. D. Strange \\ Eastern Utilization Research and Development Division, Agricultural Research Service, \\ United States Department of Agriculture, Philadelphia, Pa. USA
}

\begin{abstract}
At present, the selective filtration of smoke constituents has been limited to components sufficiently volatile to exist wholly or partially in the vapor phase. A key factor in the selective removal of potentially filterable components is the equilibrium between the two phases of the aerosol (2I). In the case of acidic and basic smoke constituents, the $\mathrm{pH}$ of the smoke is believed to be a major factor in the equilibrium. A direct relationship exists between smoke $\mathrm{pH}$ and the degree of selective filtration of nicotine using conventional cellulose acetate filters $(4,8)$. Laboratory (I) and clinical (I3) studies have shown a similar relationship between $\mathrm{pH}$ and absorption of nicotine in the buccal cavity and by simulated saliva. Some slight selective filtration of nicotine from the acidic ( $\mathrm{pH} \rightleftharpoons 6.0$ ) smoke of American blended cigarettes has been observed when cellulose acetate filters impregnated with glycerol and triacetin are used (16); among other factors, this selectivity at an acidic $\mathrm{pH}$ may be a reflection of the removal of the small amount (up to $10 \%$ ) of nicotine in the vapor phase claimed to be present in such cigarette smoke (25). In the case of the more volatile pyridine, some selective filtration is evident from the acidic smoke of American blended cigarettes (21) and from bright cigarettes of Austrian origin (12), using cellulose acetate filters. Approximately $83 \%$ of the pyridine in the mainstream smoke of American blended cigarettes is precipitated electrostatically (23) but other indirect measurements indicate that $70 \%$ of the pyridine is in the vapor phase of smoke of such cigarettes (22). Thus, the potentialities for selective removal are greater for pyridine than nicotine.
\end{abstract}

As previously noted (20), certain gaps are evident in the above studies and represent potential areas for further work. In the published studies on the filtration of bases, cigarettes containing tobaccos of different types have been used exclusively, e.g. Burley, flue-cured, etc. These types have different leaf $\mathrm{pH}$, yield smoke of different $\mathrm{pH}$, contain variable levels of bases in leaf and smoke, and have other compositional differences that

* Received for publication: 4th November 1968 may influence the patterns of burning, filtration and vapor-particulate equilibria. It would be of interest to study the effects of variable $\mathrm{pH}$ in the smoke from the same cigarette. Theoretically, this may be accomplished by the use of acidic and basic additives. As far as we are aware, only one report on altering $\mathrm{pH}$ in this matter has appeared: storage of burley cigarettes over $\mathrm{NH}_{4} \mathrm{OH}$ resulted in a small increase in smoke $\mathrm{pH}$ (14). In addition, it would be of interest to determine the effectiveness of activated carbon filters in removing pyridine and, to a lesser extent, nicotine, from smoke of different $\mathrm{pH}$. In model systems, activated carbon may retain more than $90 \%$ of the pyridine presented to the adsorbent (22) but in cigarette filters, carbon shows no increased effectiveness in nicotine removal from smoke compared to other filter materials (24). However, the effect of carbon filters in removing these bases from smoke of different $\mathrm{pH}$ has not been studied.

\section{METHODS}

\section{Cigarettes and Smoking Conditions}

All cigarettes were a commercial brand of $85 \mathrm{~mm}$ American cigarettes without filters or with filters attached as described below. The cigarettes were smoked on a constant time machine under previously described conditions using a $28 \mathrm{~mm}$ butt length (6). The smoke was passed through a Cambridge filter and the effluent was scrubbed by a trap containing $25 \mathrm{ml}$ of ${ }_{1} \mathrm{~N} \mathrm{H}_{2} \mathrm{SO}_{4}$. Five cigarettes were smoked through the pad and trap, and the pad was then macerated in $20 \mathrm{ml}$ acetone. The acetone suspension of the macerated pad was transferred to a $250 \mathrm{ml}$ distilling flask, $25 \mathrm{ml}$ of $\mathrm{IN} \mathrm{H}_{2} \mathrm{SO}_{4}$ were added and $200 \mathrm{ml}$ of steam distillate were collected and discarded. Twenty-five $\mathrm{ml}$ of $30 \% \mathrm{NaOH}$ saturated with $\mathrm{NaCl}$ were added to the distilling flask and $20 \mathrm{ml}$ of steam distillate were collected in a receiver containing 10 $\mathrm{ml}$ of phosphate buffer, $\mathrm{pH} 6.5$ (23). This receiver was then replaced by one containing $10 \mathrm{ml}$ of the same 
buffer, steam distillation was continued and $90 \mathrm{ml}$ of distillate were collected in the new receiver. The first receiver contained all the pyridine and most (about $65 \%$ ) of the nicotine alkaloids, and the second receiver contained the remainder of the alkaloids. The above acid trap containing the smoke constituents which passed the Cambridge filter was distilled independently in the same manner as the macerated pad. For each experimental condition, 4 sets of pads and acid traps were analyzed for pyridine and nicotine representing values for 20 cigarettes.

In experiments with activated carbon filter cigarettes, multiple filters containing both cellulose acetate and carbon were removed from commercial American filter cigarettes. Nineteen $\mathrm{mm}$ sections were cut from one end of the $85 \mathrm{~mm}$ nonfilter cigarettes used above and the detached filters were joined to the remaining tobacco columns by a thin width of Scotch* tape, giving cigarettes $85 \mathrm{~mm}$ in length, including the $19 \mathrm{~mm}$ filter. The same procedure was used in making the cellulose acetate filter cigarettes after first removing the carbon from the filter chamber.

Cigarettes containing additives were prepared by injection of an appropriate volume of an aqueous solution of the additive using a syringe. All cigarettes were stored over $74 \%$ glycerol in water $(\mathrm{W} / \mathrm{W})$ in a desiccator for 7-8 days before use. Under these conditions, the range of moisture values for all cigarettes was $12.0-16.9 \%$ but most cigarettes contained $14.0-15.5 \%$.

\section{Pyridine and Nicotine Analyses}

The colorimetric analysis of Asmus et al. $(2,3)$ was employed with two changes: the volumes of the reagents and sample solutions were reduced by one-fourth, and a complete spectrum $(350-700 \mathrm{~nm})$ was run using a I $\mathrm{cm}$ cuvette. Calibration curves of concentration vs. absorption at $582 \mathrm{~nm}$ for pyridine and at $510 \mathrm{~nm}$ for nicotine were obtained daily and used in calculating the amounts of the bases.

\section{3. $p H$ Determinations}

Determinations of smoke $\mathrm{pH}$ were made using the method of Grob (10) with one change: three cigarettes were smoked simultaneously instead of successively. No difference in $\mathrm{pH}$ was observed with this variation. For leaf $\mathrm{pH}$, the tobacco from 3 cigarettes was removed, suspensed in $120 \mathrm{ml} \mathrm{H}_{2} \mathrm{O}$ and stirred intermittently for $I \mathrm{hr}$ before reading on a $\mathrm{pH}$ meter. The $\mathrm{pH}$ of the tobacco in all cigarettes with additives was determined after injection of the additive into the cigarettes and storage in the desiccator as described above.

\section{TPM Determinations}

Total particulate matter (TPM) was determined by smoking 5 cigarettes through a Cambridge filter in the conventional manner and immediately weighing the filter. Four sets of filters were used to obtain a final value.

\footnotetext{
* Mention of commercial product does not imply endorsement by the Department over similar products not named.
}

\section{RESULTS}

\section{Method Specificity}

The chemistry of the analytical method has been described earlier (23). In general, the pyridine ring is split by cyanogen chloride and nitrogen is lost, forming an unsaturated, $\Delta$-hydroxyaldehyde which condenses with barbituric acid to yield a colored complex. The complexes for nicotine and pyridine absorb at different wavelengths permitting simultaneous determination of both bases. A correlation between this method and the yield of nicotine alkaloids by picric acid precipitation has been demonstrated (2). Although the method is believed to be specific for "nicotine alkaloids" and "simple pyridine bases" in smoke (23), data on this point have not appeared. Table 1 shows the absorption maxima and molar absorptivities for the reaction products of several common smoke bases in the reaction. Among the volatile bases studied, only the 4-methylpyridine product has absorptive characteristics which may contribute to the pyridine value, depending on the relative levels of each in the smoke. However, it appears that such contribution may not occur in actual smoke analyses for two reasons: the amount of 4-methylpyridine is probably much less that the levels of pyridine and 3-methylpyri-

Table 1 Speciral data on reaction products of selected simple bases and alkaloids in the Asmus et al. reaction

\begin{tabular}{l|c|c}
\hline \multicolumn{1}{c|}{ Compound } & $\lambda_{\text {max }}(\mathrm{nm})$ & $\log \varepsilon$ \\
\hline Pyridine & 582 & 5.05 \\
3-Methylpyridine & 482 & 3.37 \\
4-Methylpyridine & 604 & 4.61 \\
2,4-Dimethylpyridine & 604 & 2.81 \\
3,5-Dimethylpyridine & 604 & 2.51 \\
Nicotine & 510 & 4.33 \\
Nornicotine & 508 & 3.96 \\
Mysomine & 490 & 3.12 \\
\hline
\end{tabular}

dine in tobacco smoke $(17,18)$ and no peak or inflection is observed at $604 \mathrm{~nm}$ on actual analysis of steam distillates from smoke. In the case of the alkaloids, it is doubtful that nornicotine and myosmine contribute significantly to the nicotine value in analyses of smoke from American commercial cigarettes since the levels of the minor alkaloids are usually less than $1 \%$ of nicotine (18).

\section{Alteration of Smoke $\mathrm{pH}$}

Table 2 shows the effect of selected acidic and basic cigarette additives on the $\mathrm{pH}$ of an aqueous suspension of the tobacco and the smoke from fortified cigarettes. Among the acidic additives, the volatility of the acid is of greater importance than the acidic strength in depressing the $\mathrm{pH}$ of the smoke. The weakest acid in the group, formic acid (b.p. 100.7 $7^{\circ}$ ), is the only member which depresses the $\mathrm{pH}$ of the smoke lower than the $\mathrm{pH}$ of the tobacco extract. In all probability, formic acid largely distills into the smoke but the other acids with 
Table 2 Effect of acidic and basic additives on the pH of cigarette tobacco and smoke

\begin{tabular}{|c|c|c|c|c|}
\hline \multirow{2}{*}{ Additive } & \multirow{2}{*}{$\mathrm{pK}_{1}$} & \multirow{2}{*}{$\begin{array}{c}\text { Level } \\
\text { (mg/cig) }\end{array}$} & \multicolumn{2}{|c|}{$\mathrm{pH}$} \\
\hline & & & Tobacco & Smoke \\
\hline None & - & - & 5.5 & 5.6 \\
\hline $\mathrm{HCOOH}$ & 3.75 & 33 & 4.6 & 4.1 \\
\hline $\mathrm{H}_{2} \mathrm{SO}_{4}$ & - & 40 & 3.9 & 4.3 \\
\hline $\mathrm{H}_{3} \mathrm{PO}_{4}$ & 3.12 & 50 & 4.0 & 4.9 \\
\hline Citric acid & 3.08 & 120 & 4.3 & 5.0 \\
\hline $\mathrm{Na}_{3} \mathrm{PO}_{4}$ & 1.33 & 134 & 7.8 & 6.8 \\
\hline $\mathrm{Na}_{2} \mathrm{CO}_{3}$ & 3.75 & 40 & 8.0 & 6.4 \\
\hline $\mathrm{NH}_{4} \mathrm{OH}$ & 4.75 & 11 & 8.5 & 7.8 \\
\hline Diethylamine & 2.90 & 140 & 7.4 & 8.1 \\
\hline Dipropylamine & 3.09 & 100 & 7.5 & 8.2 \\
\hline
\end{tabular}

higher boiling or decomposition points tend to distill less into the smoke and/or form volatile products which influence the smoke $\mathrm{pH}$ less markedly. Among the basic additives, dipropylamine (b.p. 109.4 $4^{\circ}$ C) and diethylamine (b.p. $56,3^{\circ} \mathrm{C}$ ) probably act in the same general manner as formic acid in influencing the $\mathrm{pH}$ of the smoke. Ammonium hydroxide is not as effective as the aliphatic amines possibly due to a large proportion of distilled $\mathrm{NH}_{3}$ remaining in the gas phase and not being measured by the $\mathrm{pH}$ technique employed.

\section{Composition and Filtration of Control Cigarettes}

In the control cigarettes without additives an increase in smoke $\mathrm{pH}$ is noted when filters containing cellulose acetate alone and in combination with activated carbon are employed (Table 3). However, the presence of carbon causes little change in the TPM; thus, the presence of the empty chamber resulting when the carbon is removed from the commercial filter does not alter to any great extent the gross filtration, which confirms other indirect findings on this point (21).

The combined carbon-cellulose acetate filter gives a

Table 3 Effect of acidic and basic additives on the composition and filtration of smoke from commercial cigarettes

\begin{tabular}{|c|c|c|c|c|c|c|}
\hline \multirow{2}{*}{ Additive } & \multirow{2}{*}{ Filter* } & \multirow{2}{*}{$\begin{array}{c}\text { Smoke } \\
\mathrm{pH}\end{array}$} & \multirow{2}{*}{$\begin{array}{c}\mathrm{TPM}^{* *} \\
(\mathrm{mg} / \mathrm{cig})\end{array}$} & \multicolumn{2}{|c|}{ Pyridine** } & \multirow{2}{*}{$\begin{array}{l}\text { Nicotine** } \\
\text { (mg/cig) }\end{array}$} \\
\hline & & & & $\%$ in trap & Total ( $\mu \mathrm{g} / \mathrm{cig})$ & \\
\hline \multirow[t]{3}{*}{ None } & None & 5.6 & $24.2 \pm 1.6$ & $67.7 \pm 6.9$ & $27.5 \pm 3.8$ & $1.73 \pm .10$ \\
\hline & $\mathrm{CH}$ & 6.1 & $15.3 \pm 0.6$ & $58.5 \pm 1.4$ & $4.8 \pm 0.5$ & $1.12 \pm .09$ \\
\hline & CA & 5.8 & $17.5 \pm 1.3$ & $72.7 \pm 5.6$ & $18.5 \pm 2.3$ & $1.17 \pm .03$ \\
\hline \multirow[t]{3}{*}{ Formic Acid } & None & 4.1 & $32.0 \pm 1.9$ & $34.5 \pm 1.4$ & $9.7 \pm 2.0$ & $2.34 \pm .03$ \\
\hline & $\mathrm{CH}$ & 4.9 & $18.0 \pm 0.6$ & $38.9 \pm 4.7$ & $3.7 \pm 0.3$ & $1.20 \pm .18$ \\
\hline & CA & 4.4 & $25.5 \pm 2.9$ & $50.6 \pm 2.2$ & $7.7 \pm 1.8$ & $1.82 \pm .16$ \\
\hline \multirow[t]{3}{*}{ Dipropylamine } & None & 8.2 & $30.8 \pm 1.1$ & $68.6 \pm 4.0$ & $26.5 \pm 1.9$ & $2.01 \pm .29$ \\
\hline & $\mathrm{CH}$ & 7.9 & $24.7 \pm 1.2$ & $67.1 \pm 3.0$ & $10.0 \pm 1.8$ & $1.27 \pm .15$ \\
\hline & CA & 7.9 & $24.5 \pm 0.5$ & $73.3 \pm 1.8$ & $26.2 \pm 2.0$ & $1.11 \pm .16$ \\
\hline
\end{tabular}

* $\mathrm{CH}=$ activated carbon + cellulose acetate, $\mathrm{CA}=$ cellulose acetate

** Average \pm 1 standard deviation

high degree of selectivity for pyridine removal in the control cigarettes (Table 4 ) and the carbon portion of the filter is primarily responsible for this effect. Calculations of S values (7) by George and Keith (9) using the data of Waltz and Häusermann (21) show slight selectivity ( $S=1.2-1.5$ ) for pyridine removal by cellulose acetate filters which is not readily apparent in the filter used in these cigarettes (Table 4); however, the variability in TPM in Table 3 is such that some slight selectivity may exist. In Table 3 some difference is evident in the percentage of pyridine which passes through the Cambridge pad for the 3 cigarettes without additives. Whether or not these values represent a valid indication of the proportion of pyridine in vapor and particulate phases is not known. Generally, the values compare favorably with other indirect findings showing $70 \%$ pyridine in the vapor phase of cigarette smoke (22).

Nicotine is not removed selectively to any significant extent by the cellulose acetate filter with or without the activated carbon, which confirms previous work $(16,21)$. Slight selectivity of nicotine $(S=\sim 1.35)$ from domestic cigarette smoke is only observed when certain addi- tives are employed with cellulose acetate filters, e.g. glycerol and triacetin (I6).

Since Cambridge filters retain all the nicotine from both acidic and alkaline smoke (25), no nicotine is found in the acid traps.

Table 4 Selectivity values for pyridine and nicotine removal from cigarette smoke of different $\mathrm{pH}$

\begin{tabular}{|c|c|c|c|c|}
\hline \multirow{2}{*}{\multicolumn{2}{|c|}{ Additive }} & \multirow{2}{*}{ Filter* } & \multicolumn{2}{|c|}{ S values** } \\
\hline & & & Pyridine & Nicotine \\
\hline \multirow{2}{*}{\multicolumn{2}{|c|}{ None }} & $\mathrm{CH}$ & 3.62 & 0.98 \\
\hline & & CA & 1.08 & 1.07 \\
\hline \multirow{2}{*}{\multicolumn{2}{|c|}{$\mathrm{HCOOH}$}} & $\mathrm{CH}$ & 1.47 & 1.09 \\
\hline & & CA & 1.00 & 1.02 \\
\hline \multirow{2}{*}{\multicolumn{2}{|c|}{ Dipropylamine }} & $\mathrm{CH}$ & 2.12 & 1.28 \\
\hline & & CA & 0.81 & 1.44 \\
\hline \multicolumn{5}{|c|}{$\begin{array}{l}* \mathrm{CH}=\text { charcoal }+ \text { cellulose acetate, } \mathrm{CA}=\text { cellulose acetate } \\
\mathrm{W}_{U}(\mathrm{X})\end{array}$} \\
\hline \multirow{3}{*}{${ }^{* *} \mathrm{~S}=$} & $W_{u}(p)$ & \multirow{3}{*}{\multicolumn{3}{|c|}{$\begin{array}{l}\text { in which } W=\text { weight, } u=\text { unfiltered smoke, } \\
f=\text { filtered smoke, } p=\text { particulate matter in } \\
\text { smoke and } X=\text { pyridine or nicotine in smoke. }\end{array}$}} \\
\hline & $W_{f}(X)$ & & & \\
\hline & & & & \\
\hline
\end{tabular}




\section{Changes in Composition and Filtration: Acidic Smoke}

The addition of formic acid to nonfilter cigarettes in the amount shown in Table 2 results in a marked increase in TPM (Table 3). All or part of this effect may be due to volatilization of the additive and ultimate deposition in the particulate matter. The increase may also be a reflection of a nonspecific alterration in the burn pattern due to the additive (and possibly unrelated to the $\mathrm{pH}$ effect since the pyridine: nicotine ratio is changed (vide infra). Other workers have shown that yields of TPM are quite variable when additives are employed in cigarettes (5). However, the percentage of formic acid used here is lower than the levels of additives usually employed to obtain changes in burn temperature and levels of TPM and other smoke constituents $(5,11,15)$. The addition of formic acid results in a significant decrease in the amount of pyridine passing the Cambridge pad. The dissociation constant of pyridine is $1.71 \times 10^{-9}$ equivalent to a $\mathrm{pH}$ of 5.23 . Thus, in the $\mathrm{pH} 5.6$ smoke from the nonfilter control cigarettes, the ratio of salt: base is theoretically 0.42 but in the corresponding cigarettes with formic acid, the calculated ratio is 13.6 so that significantly more pyridine would be expected in the particulate phase. Although the observed values for the proportions of pyridine passing the Cambridge pad do not follow these calculations quantitatively, the general trend is evident.

The relative pattern of the total pyridine levels in the unfiltered and filtered smoke from cigarettes containing formic acid follows that of the control cigarettes. However, the selectivity of pyridine removal for the multiple filter is much lower compared to the control cigarettes (Table 4). No selectivity of pyridine removal from smoke at $\mathrm{pH}_{4.4}$ is observed with the cellulose acetate filter.

The nicotine level of unfiltered smoke from the cigarettes with formic acid is considerably higher than the unfiltered control smoke of $\mathrm{pH}$ 5.6. This together with the greatly reduced pyridine level in unfiltered smoke may indicate that a basic alteration in the kinetics of nicotine pyrolysis is occurring. Since leaf nicotine is a primary source of pyridine in smoke (19), a reduction in the degree of ring scission in the methylpyrrolidinyl moiety of nicotine would be reflected in lower pyridine and higher nicotine levels in smoke. Based on the dissociation constants of nicotine $\left[1.4 \times 10^{-11}\right.$ (pyridyl) and $7.0 \times 10^{-7}$ (methylpyrrolidinyl)], the alkaloid will exist predominantly as the mono salt in the approximate $\mathrm{pH}$ range of 3.2-7.8. Thus, there should be little change expected in the filtration pattern of nicotine in the smoke from the control cigarettes at $\mathrm{pH}$ 5.9-6.1 and the acidic cigarettes at $\mathrm{pH} 4.4-4.9$ due exclusively to $\mathrm{pH}$ effects. The selectivity values (Table 4 ) indicate that such is the case.

A significantly large increase in TPM occurs when carbon is removed from the multiple filter. The reason for this effect is not known. Possibly, the presence of relatively large amounts of additive in the smoke may produce changes in the adsorptive characteristics of the carbon and alterations in particle size which together produce this effect.

\section{Changes in Composition and Filtration: Alkaline Smoke}

On adding dipropylamine to commercial cigarettes in the amount listed in Table 2, an increase in TPM over the control cigarettes is noted (Table 3). Possible explanations for this are discussed above. The levels of pyridine and nicotine obtained in the unfiltered alkaline smoke are similar to those of unfiltered control smoke, showing that the apparent alteration of nicotine pyrolysis which occurred in acidic ( $\mathrm{pH}_{4.1}$ ) smoke does not occur in the alkaline smoke.

The TPM levels with the multiple filter and the cellulose acetate filter are the same, and parallel the findings in the control smoke. Surprisingly, the degree of selectivity for pyridine is less in the alkaline smoke passing through the multiple filter than in the comparable control smoke (Table 4 ). On the other hand, a slight selectivity of nicotine removal is evident in the multiple filter.

The small reversed selectivity for pyridine with the cellulose acetate filter may be the result of some unusual physiochemical effect on the filter surface due to the presence of large amounts of additive in the smoke. Apparently, this effect does not influence the filtration of nicotine since enhanced selectivity is observed, as expected. Calculation of the salt: free base ratio of nicotine in solution at $\mathrm{pH} 7.9$ gives a value of 0.88 . Assuming this proportion exists in smoke and all the nicotine in the free base form is filtered out, a theoretical selectivity value of 1.72 would be obtained. The observed values for both filters are somewhat lower than the theoretical filtration efficiency, and other factors may be influencing the partitioning or filtration of the alkaloid under these conditions.

\section{SUMMARY}

Using selected additives, the $\mathrm{pH}$ of smoke from U. S. commercial cigarettes (5.6) can be altered over a wide range (4.I-8.2). The volatility of the additive is of greater importance in changing smoke $\mathrm{pH}$ than the acidic or basic strength of the additive. The activated carbon in multiple carbon-cellulose acetate filters is highly effective in removing pyridine selectively from the smoke of blended commercial cigarettes. The degree of this selectivity is markedly reduced on lowering the smoke $\mathrm{pH}$ to 4.1 by adding formic acid to cigarettes. On raising the $\mathrm{pH}$ of smoke to 8.2 by adding dipropylamine to cigarettes, the selectivity for pyridine is less than in smoke of unaltered $\mathrm{pH}$ and more than in smoke of $\mathrm{pH}$ 4.1. Some selectivity of nicotine removal is observed in the alkaline smoke using cellulose acetate filters with or without carbon. The use of formic acid to depress $\mathrm{pH}$ appears to alter the kinetics of nicotine pyrolysis, resulting in a changed nicotine:pyridine ratio. 


\section{ZUSAMMENFASSUNG}

Durch ausgewählte Zusätze zum Tabak handelsüblicher amerikanischer Cigaretten können die pH-Werte $(5,6)$ innerhalb einer weiten Spanne $(4, I$ bis 8,2$)$ verändert werden. Für die Änderung der pH-Werte des Rauches ist die Flüchtigkeit des Zusatzes wichtiger als seine Stärke als Säure oder Base. Für die selektive Retention von Pyridin aus dem Rauch handelsüblicher amerikanischen Blendcigaretten hat sich Aktivkohle in Mehrfachfiltern (Kohle-Celluloseacetat) als außerordentlich wirksam erwiesen. Diese selektive Wirkung wird deutlich vermindert, wenn der $\mathrm{pH}-$ Wert des Rauches durch $\mathrm{Zu}$ satz von Ameisensäure zum Tabak auf 4,I gesenkt wird. Wird der pH-Wert des Rauches durch Zusatz von Dipropylamin zur Cigarette auf 8,2 erhöht, ist die Selektivität gegenüber Pyridin geringer als wenn der $\mathrm{pH}-$ Wert unbeeinflußt bleibt und höher als bei einem $\mathrm{pH}$ des Rauches von 4,I. Bei Celluloseacetat-Filtern mit oder ohne Zusatz von Kohle ist eine gewisse Selektivität der Nikotin-Retention zu beobachten sofern der Rauch alkalisch ist. Wird der pH-Wert durch Ameisensäure herabgesetzt, so scheint dies die Kinetik der Nikotinpyrolyse und das Verhältnis Nikotin:Pyridin zu verändern.

\section{RÉSUMÉ}

Par l'emploi d'additifs convenables, le $\mathrm{pH}$ de la fumée des cigarettes US du commerce $\left(\mathrm{pH}_{5}, 6\right)$ peut être fortement modifié (de $\mathrm{pH} 4,1$ à $\mathrm{pH} 8,2$ ). Pour la modification du $\mathrm{pH}$, la volatilité de l'additif a plus d'importance que son degré d'acidité ou d'alcalinité. Le charbon activé des filtres composites charbonacétate de cellulose a une grande efficacité de rétention sélective de la pyridine présente dans la fumée des cigarettes commerciales en mélanges de tabacs. Cette sélectivité est fortement réduite lorsqu'on abaisse à 4,1 le $\mathrm{pH}$ de la fumée par addition d'acide formique aux cigarettes. Quand le $\mathrm{pH}$ de la fumée est porté à 8,2 par addition de dipropylamine aux cigarettes, la sélectivité vis à vis de la pyridine est moindre que lorsque le $\mathrm{pH}$ de la fumée n'est pas modifié, et plus grande que lorsqu'il est abaissé à $4, I$. Lorsque la fumée est alcaline, les filtres en acétate de cellulose, avec ou sans charbon, présentent une certaine sélectivité de la rétention de la nicotine. L'utilisation d'acide formique pour abaisser le $\mathrm{pH}$ paraît modifier la cinétique de la pyrolyse de la nicotine et, en conséquence, conduire à une modification du rapport nicotine/pyridine.

\section{LITERATURE}

1. Artho, A. J., and Grob, K.: Z. Präventivmed. 9 (1964) 14.

2. Asmus, E., Höhne, R., and Kraetsch, J.: Z. Anal. Chem. 187 (1962) 33.

3. Asmus, E., and Papenfuß, D.: Ibid 185 (1962) 201.

4. Ayres, C. I., and Evelyn, S. R.: 18th Tobacco Chemists' Research Conference, Raleigh, N. C., 1964.

5. Burdick, D., unpublished findings.

6. Burdick, D., and Stedman, R. L.: Tobacco Sci. 7 (1963) 113.

7. Davis, H., and George, W.: Bull. Inform. CORESTA No. I (1965) 7.

8. Fordyce, W. B., and Horsewell, H. G.: 19th Tobacco Chemists Research Conference, Lexington, Ky., 1965.

9. George, T. W., and Keith, C. H. in reference 25, pp 595-608.

10. Grob, K., Beitr. z. Tabakforsch. I (1963) 97.

11. Hoffmann, D., and Wynder, E. L.: Cancer Res. 27 (1967) 172.

12. Kuhn, H.: Fachl. Mitteil. Österreich. Tabakregie No. 6 (1966) 89.

13. Larson, P. S., Haag, H. B., and Silvette, H.: Tobacco, Experimental and Clinical Studies, Baltimore, Md., Williams \& Wilkins Co., 1961, p. 5.

14. Lipp, G.: Beitr. z. Tabakforsch. 3 (1965) Iog.

15. Miller, F., Freeman, W. J., and Stedman, R. L.: Beitr. z. Tabakforsch. 4 (Ig68) 269.

16. Mumpower, R. C., and Kiefer, J. E.: Tobacco Sci. II (1967) I44.

17. Osman, S., and Barson, J.: Phytochem. 3 (1964) 587.

18. Schmeltz, I., Stedman, R. L., Chamberlain, W. J., and Burdick, D.: J. Science Food Agr. 15 (1964) 774.

I9. Stedman, R. L.: Chem. Rev. 68 (I968) I53.

2o. Stedman, R. L.: U. S. Nat. Cancer Inst. Monograph No. 28 (1968) 113.

21. Waltz, P., and Häusermann, M.: Beitr. z. Tabakforsch. 3 (1965) 169.

22. Waltz, P., Häusermann, M., and Hirsbrunner, R.: Bull. Inform. CORESTA No. 3 (I966) 82.

23. Waltz, P., Häusermann, M., and Moser, F.: Beitr. z. Tabakforsch. 2 (1964) 283.

24. Williamson, J. T., Graham, J. F., and Allman, D. R.: Beitr. z. Tabakforsch. 3 (1965) 233.

25. Wynder, E. L., and Hoffmann, D.: Tobacco and Tobacco Smoke; Studies in Experimental Carcinogenesis, New York, Academic Press, 1967, p. 165.

Authors' address:

Eastern Utilization Research and Development Division of Agriculture, Philadelphia, Pa., 19118, USA

of Agriculture, Philadelphia, Pa., 19118, USA 